\title{
The baton passes on, again!
}

\author{
Mario J. Soares $\mathbb{1}^{1}$
}

Received: 14 November 2020 / Accepted: 19 November 2020 / Published online: 15 January 2021

(c) The Author(s), under exclusive licence to Springer Nature Limited part of Springer Nature 2021

The history of the European Journal of Clinical Nutrition (EJCN) has been well documented within its pages $[1,2]$, and grew from the idea of being a uniting forum for clinical nutrition in Europe. Starting with the founding Editor in Chief, John C Waterlow, the journal has seen many accomplished scientists take over the leadership of the journal. Manfred J Müller joined EJCN as its Deputy Editor, and then took over the reins from Prakash Shetty in 2013. A world leader in body composition and human energy metabolism, Manfred has made many significant contributions to his field. The fervour and precision applied to his research, was evident in his daily running of the journal and in his vision for EJCN [3]. We have made great progress across many fronts, and thanks to his wonderful talent in photography, EJCN now presents a fresh face with each published issue! Manfred and I first met in 2016, soon after my appointment as Co-Editor in Chief. Despite the many challenges of the position, it has been a wonderful and fruitful partnership. Words of advice, animated discussions over the merits of certain papers or nutrition policy documents, plans for special issues, key appointments to the board, were all shared through a camaraderie that contradicted the time zones and physical distance between us. On behalf of the Associate Editors, the Editorial Board, the Publishing Editor and our readership, I thank him for his excellent stewardship of EJCN over many years. And so the baton passes on, again!

We are a hybrid journal, without society links, that covers a broad scope of nutritional issues. In today's publishing environment of targeting specialist areas and open access of published papers, our position presents a multi-faceted challenge to stay competitive and be relevant. Despite our name, successive editors have always been concerned with

Mario J. Soares

m.soares@curtin.edu.au

1 Nutrition \& Dietetics, School of Public Health, Curtin University, Perth, WA 6102, Australia global health and this is reflected in our content that showcases nutritional issues of countries outside Europe [4]. More recently, we have devoted significant space in highlighting contemporary issues from India, China and Japan, with countries like Africa and South America to follow. It is therefore gratifying to see a steady increase in our impact, a significant improvement in our journal metrics, and a pronounced surge in new submissions to the journal. It is critical to EJCN's future growth that we embrace the need for specific expertise and international presence on the board, as well as adopt current directions in academic publishing. We will also return to the roots of our organisational structure [1]. Two new deputy editors have been appointed and they will assist the Editor in Chief, in the day-to-day administration of the journal and be responsible for its scientific content. Prof. Claudio Maffeis has served us for a while now as an Associate Editor, and will step up to this new role. Claudio is a paediatrician with strong interests in paediatric obesity, diabetes and metabolism. Prof Manuela Merli is new to EJCN, and comes with abundant experience from other journals and learned organisations. As a clinician with a strong track record in nutrition and hepatology, Manuela will fulfil our longstanding wish to strengthen the clinical nutrition focus. Readers will also notice a refreshed and expanded board of associate editors and statistical editors from around the world. They all play an important role in ensuring the rigour of submissions to EJCN. I assure the readership that the combined decisions of our editorial board will always be fair, and in the greater interest of the science. Finally, I wish to thank all authors for their continued support of the journal, and look forward to receiving their valuable research in the years ahead. We have all come through a very difficult and unprecedented 2020. May the New Year restore hope, and bring about a stronger drive to research what is best for the public good.

\section{Compliance with ethical standards}

Conflict of interest The author declares no conflict of interest. 
Publisher's note Springer Nature remains neutral with regard to jurisdictional claims in published maps and institutional affiliations.

\section{References}

1. Seidell J, Shetty PS. Editorial. The baton passes on.... Eur J Clin Nutr. 2007;61:1-2. https://doi.org/10.1038/sj.ejcn.1602587.
2. Shetty P. Editorial. A progress report and a tribute to our founding editor. Eur J Clin Nutr. 2011;65:1-2. https://doi.org/10.1038/ejen. 2010.271.

3. Muller MJ. Editorial: a new editor takes over. Eur J Clin Nutr. 2012;66:1-2. https://doi.org/10.1038/ejen.2011.185.

4. Soares MJ, Müller MJ. Editorial. Thirty years of EJCN: a time for reflection. Eur J Clin Nutr. 2018;72:1195-7. https://doi.org/10. 1038/s41430-018-0201-3. 